\title{
Miranda
}

Revue pluridisciplinaire du monde anglophone /

Multidisciplinary peer-reviewed journal on the English-

speaking world

19 | 2019

Rethinking Laughter in Contemporary Anglophone Theatre

\section{James Gifford. A Modernist Fantasy: Modernism, Anarchism, and the Radical Fantastic.}

\section{Béatrice Duchateau}

\section{(2) OpenEdition}

\section{Journals}

\section{Electronic version}

URL: http://journals.openedition.org/miranda/22082

DOI: 10.4000/miranda.22082

ISSN: 2108-6559

\section{Publisher}

Université Toulouse - Jean Jaurès

Printed version

Date of publication: 7 October 2019

\section{Electronic reference}

Béatrice Duchateau, "James Gifford. A Modernist Fantasy: Modernism, Anarchism, and the Radical

Fantastic.", Miranda [Online], 19| 2019, Online since 15 October 2019, connection on 16 February 2021.

URL: http://journals.openedition.org/miranda/22082 ; DOI: https://doi.org/10.4000/miranda.22082

\section{This text was automatically generated on 16 February 2021}

\section{(c) $(1)$}

Miranda is licensed under a Creative Commons Attribution-NonCommercial-NoDerivatives 4.0 International License. 


\title{
James Gifford. A Modernist Fantasy:
} Modernism, Anarchism, and the Radical Fantastic.

\author{
Béatrice Duchateau
}

\section{REFERENCES}

James Gifford. A Modernist Fantasy: Modernism, Anarchism, and the Radical Fantastic. Victoria: ELS Editions, 2018 


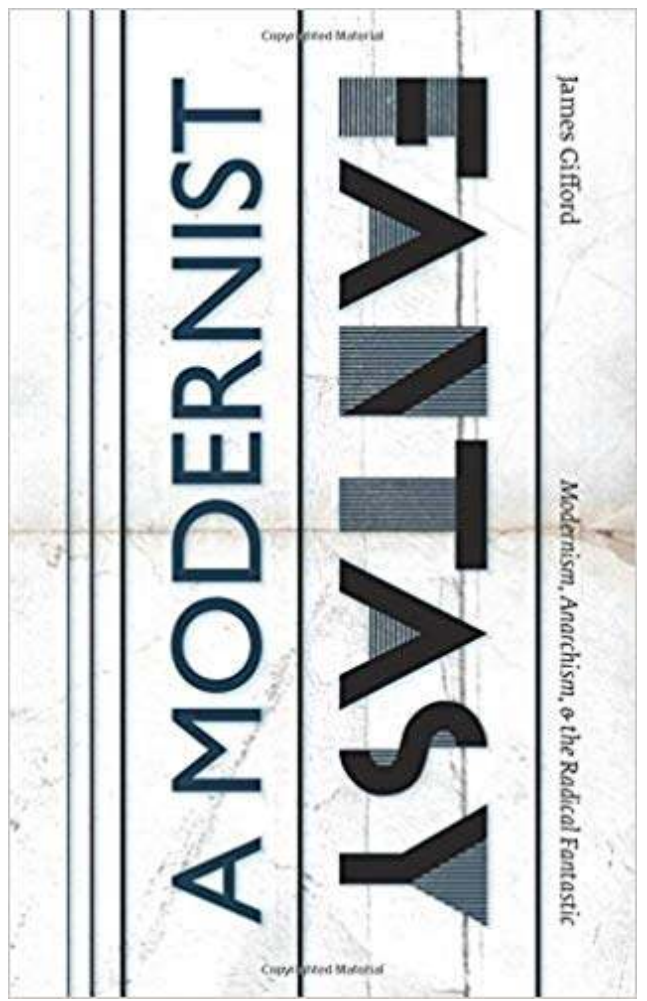

1 James Gifford's A Modernist Fantasy: Modernism, Anarchism, and the Radical Fantastic (2018) is openly part of the New Modernist Studies as it provides the reader with a journey into a counter-canon of fantasy that challenges the boundaries set between high and popular culture. Gifford's audacious project is intended at "rethinking modernism" (p.xii), especially late modernism, through the prism of fantasy and anarchism. Through the case studies of nine authors, his book aims at disclosing how the three apparently contradictory fields of modernism, anarchism and fantasy, were in fact overlapping from the 1890s until the 1970s. The other goal of the study is to make an anti-authoritarian trend of fantasy visible, to reveal a lineage of fantasy writing that has been hidden by the overarching influence of J. R. R. Tolkien's work.

2 The book is divided into four chapters: the first one is devoted to what Gifford calls his "metacritical" project (p. 7), which is a substantial critique of how fantasy was defined and tackled through both structuralist and materialist approaches. The following three chapters offer a chronological overview of how modernism, anarchism and fantasy coincided in the works of late Victorian and high modernist writers first, then in the works of late modernist writers in the 1940s-1960s, and finally in the works of postmodern writers till the end of the 1980s.

3 The first chapter opens with a criticism of the structuralist approach to fantasy that was mostly definition-based but it then quickly turns to an attack on the critical methodology that has prevailed in the scholarly criticism of the genre since the 1970s: the materialist approach which contributed to the creation of a canon of fantasy. Gifford endeavours to provide a very detailed and referenced analysis of the theories developed by Fredric Jameson or Darko Suvin, among others: they have all described fantasy as reactionary or conservative through the study of different common features such as metonymy, the struggle between good and evil, medievalism, and magic, which, according to them, condone and even strengthen gender and class boundaries or 
ethnocentrism. Anarchism was regarded in exactly the same way by those critics. As a result of such considerations, fantasy has often been held inferior to science fiction, whose more open social criticism or utopian projections would seem to weaken class distinctions or cultural hegemonies more overtly. In addition, since fantasy was being reduced to reactionary medievalism, every alternative piece of fantasy work that was not fitting this definition was neglected as not considered worthy of interest. This was compounded by the commercial success of Tolkien and his imitators. Gifford explains that the anarchist or anti-authoritarian stance present in such works could not be analysed properly by Marxist critics (or ones influenced by Marxist paradigms) because their understanding of notions such as subjectivity or authority differed too strongly from an anarchist perspective; their assimilation of anarchism to individualism for example made it impossible for them to acknowledge their potential for political and ontological change. After showing the limitations of fantasy scholars, the author then exposes the short-comings of another field of criticism, that of modernism and late modernism. Another reason for the disregard in which many fantasy writers of the period were held captive is the preference for science fiction that was connected more readily to modernism. The impossibility to consider an alternative set of writers and their other version of subjectivity was amplified as well by the editorial and theoretical dominance of the Auden generation. Science fiction, realism and modernism were studied in smooth relation when it seemed impossible to link fantasy to modernism(s). Finally, the chapter then closes on a presentation of this counter-canon defended enthusiastically by Gifford. He dates back the beginning of this alternative fantasy canon in the New Apocalypse Movement, a post-surrealist movement born in England before the Second World War, a movement influenced by the anarchist writings of Henry Miller and Herbert Read. Before and after the war, a number of writers belonging to the late modernist trend, such as Mervyn Peake or George Woodcock, turned to fantasy while retaining their writing style. They would in turn influence a later generation of writers like Ursula K. Le Guin or Samuel Delany in the late 1960s and 1970s. Gifford highlights the fact that those authors retained a modernist interest in tradition and myth, and stream of consciousness, as a way to interpret and challenge modern society. He contends as well that their works undermine capitalism and Marxist paradigms through reflexions on power and the rejection of determinism. Gifford's arguments in this lengthy chapter are engaging and multifaceted but sometimes tend to get lost in the number of references he uses to make his point.

The second chapter moves on to the analysis of the texts and starts with the study of early fantasy works which helped the genre develop and included antiauthoritarian ideas. Gifford begins with the study of William Morris's The Wood Beyond the World (1894) with two goals in mind: showing first that Morris sympathised with anarchist ideas and that his use of a secondary world was not reactionary. He celebrated individuality and rejected "the state and concentration of power" (p. 97) in the form of a pre-modern society where kinship does not exist. Lord Dunsany's The King of Elfland's Daughter (1924) is quickly conjured to oppose its conservative forms of social organisation to the modernist Hope Mirlee's Lud-in-the-Mist (1924), where Gifford studies the function of authority, law, power and death, and their relation. In both Morris's and Mirlee's works, the author identifies the desire to criticise the accumulation of authority, of state power, rather than the economic forces and the accumulation of capital. In this rather too brief a chapter, a more profound analysis of the style of the writers, especially that of the modernist Mirlee, would have been welcome as only diegetic 
analyses are provided. If the bridge made between anarchism and fantasy is very convincing, the connection between modernism and fantasy would have gained in strength through a more thorough textual examination.

The next chapter then charts the works of four authors who wrote between the 1940s and 1960s in an anarchist vein: Mervyn Peake, Henry Treece, Poul Anderson, the only American writer studied, and John Cowper Powys. In Peake's Gormenghast series, the antiauthoritarian stance is for example personified by the escape of Titus into the organic natural world; he flees from a castle and its rituals that embody the forces of social determination. The analysis of Anderson's The Broken Sword (1954) depicts how power is represented as fostering corruption, how heroism is rejected, and how a reforged sword can be a metaphor for the atomic bomb. Through the study of Powys's Porius (1951), Gifford then shows how the themes of pluralism and individuality can be tackled in an anti-authoritarian fantasy novel, and he explores the symbolism of the confrontation of the mist and the wind, how the former is linked to power and how the latter embodies rebellion. The last works mentioned are Henry Treece's Legions of the Eagles (1954) and The Golden Strangers (1956) in which the main characters turn to organic nature as well. All the novels considered in this chapter have in common the themes of power and domination, they resist the concepts of heroism and economic determinism, and they promote new forms of selfhood and personal freedom. Their style is more experimental than Tolkien's but, once again, despite a few considerations on stream of consciousness, the analysis would have gained in demonstrating more openly how, as the author claims, the "liberatory political praxis" of these writers is embodied "in form rather than [...] in content" (p. 8).

The last chapter successfully shows how the generation tackled in section three influenced the post-1960s generation and focuses first on Ursula K. Le Guin's Earthsea series (1964-2001). Constantly set against Jameson's views on Le Guin's work, Gifford's demonstration weaves through the anarchist themes present in the series: resistance to closure as a form of rebellion against authority, disruption of the good/evil standard dichotomy, or self-possession as the only path to freedom. Self-possession is addressed as well in Michael Moorcock's Gloriana, or The Unfulfill'd Queen (1978) through the release of the eponymous character in orgasm and rape. Finally, the author demonstrates how Samuel Delany's political and theoretical perspective evolved in the Nevèrÿon series (1979 to 1987), progressing from the determinism of Marxism to a reflexion on power more like Michel Foucault's.

7 In this stimulating and energetic study of nine writers, the extensive familiarity of the author with the two fields of criticism conjured, modernism and fantasy, is impressive; Gifford's work successfully contributes to challenge both the canons of (late) modernism and fantasy, especially when he forces the reader to review his or her standards and to discard his or her preconceptions on fantasy. To that end, the author systematically recourses to a comparison to Tolkien's Lord of the Rings. The trilogy is always referred to as a point of reference to establish the differences between the main fantasy canon of the 'Inklings' and the counter-canon presented by the author, making the consideration of this alternative stream of fantasy very conclusive. Gifford's goal was to make us "pick-up some fantasy novels with an open-mind" (p. xii), and in this, he has been very successful. 
INDEX

Keywords: Fantasy, anarchism, modernism, late modernism, materialism, Marxism, New Apocalypse Movement, individualism, determinism

Mots-clés: Fantasy, anarchisme, modernisme, late modernism, matérialisme, Marxisme, New Apocalypse Movement, individualisme, déterminisme

\section{AUTHORS}

\section{BÉATRICE DUCHATEAU}

Professeur agrégée des universités Université de Bourgogne

beatrice.duchateau@u-bourgogne.fr 